\title{
Strain of Bacillus thuringiensis from Restinga, toxic to Aedes (Stegomyia) aegypti (Linnaeus) (Diptera, Culicidae)
}

\author{
M. R. A. Vieira-Neta ${ }^{a}$ (D), J. Soares-da-Silva ${ }^{\text {(D), J. L. Viana }}$ (D), M. C. Silva ${ }^{d}$ (D), \\ W. P. Tadei iD $^{\text {and V.C.S. Pinheiro }}{ }^{f *}$ \\ aUniversidade Estadual do Maranhão - UEMA, Programa de Pós-graduação em Biodiversidade, Ambiente e Saúde - \\ PPGBAS, Caxias, MA, Brasil \\ bUniversidade Federal do Maranhão - UFMA, Coordenação de Ciências Naturais/Biologia, Codó, MA, Brasil \\ 'Universidade do Estado do Amazonas - UEA, Programa de Pós-graduação em Biodiversidade e Biotecnologia da Rede \\ BIONORTE - PPG BIONORTE, Manaus, AM, Brasil \\ dUniversidade Estadual do Maranhão - UEMA, Centro de Estudos Superiores de Caxias - CESC, Departamento de \\ Química e Biologia, Caxias, MA, Brasil \\ 'Instituto Nacional de Pesquisas da Amazônia - INPA, Laboratório de Malária e Dengue, Programa de Pós-graduação em \\ Entomologia, Manaus, AM, Brasil

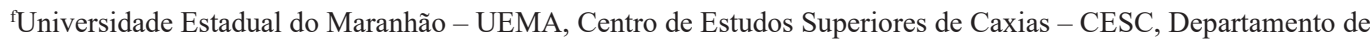 \\ Química e Biologia, Laboratório de Entomologia Médica - LABEM, Caxias, MA, Brasil \\ *e-mail: vc_pinheiro@hotmail.com
}

Received: September 16, 2019 - Accepted: April 20, 2020 - Distributed: November 30, 2021

(With 2 figures)

\begin{abstract}
Bacillus thuringiensis is the most commonly used entomopathogen in the control of Aedes aegypti, which is a vector for different etiological agents that cause serious infections in humans. Several studies aim to isolate strains of this bacterium from different environments, with the perspective of selecting isolates with larvicidal activity for mosquitoes. Aiming at the insecticidal action of $B$. thuringiensis, the present study aimed to prospect $B$. thuringiensis of restinga and mangrove soils from the state of Maranhão, Brazil, with toxic potential for use in the biological control of Ae. aegypti. Bioassays were performed to determine the entomopathogenic activity of the bacilli against Ae. aegypti and lethal concentrations $\left(\mathrm{LC}_{50}\right.$ and $\mathrm{CL}_{90}$ ) were estimated after the tests. Polymerase Chain Reaction and SDS-PAGE techniques were performed to verify the gene and protein content of the isolates, respectively. The soil of the mangrove and restinga ecosystems showed potential for obtaining $B$. thuringiensis. This isolate, in addition to having proteins with molecular mass similar to the toxins Cry and Cyt, also presented several diptera-specific genes cry and cyt, demonstrating that it has high potential to be used in the biological control of Ae. aegypti.
\end{abstract}

Keywords: biological control, bacteria, ecosystem, vector.

\section{Estirpe de Bacillus thuringiensis da restinga, tóxico ao Aedes (Stegomyia) aegypti (Linnaeus) (Diptera, Culicidae)}

\begin{abstract}
Resumo
Bacillus thuringiensis é o entomopatógeno mais utilizado no controle do Aedes aegypti, vetor de diferentes agentes etiológicos que causam infecções graves em humanos. Diversos estudos têm como objetivo isolar cepas dessa bactéria de diferentes ambientes, com a perspectiva de selecionar isolados com atividade larvicida para mosquitos. Visando a ação inseticida de $B$. thuringiensis, o presente estudo teve como objetivo prospectar $B$. thuringiensis de solos de restinga e mangue do estado do Maranhão, Brasil, com potencial tóxico para uso no controle biológico de Ae. aegypti. Bioensaios foram realizados para determinar a atividade entomopatogênica do bacilo contra Ae. aegypti e as concentrações letais $\left(\mathrm{CL}_{50}\right.$ e $\left.\mathrm{CL}_{90}\right)$ foram estimadas após os testes. As técnicas de Reação em Cadeia da Polimerase e SDS-PAGE foram realizadas para verificar o conteúdo de genes e proteínas dos isolados, respectivamente. Os solos dos ecossistemas de mangue e restinga apresentaram potencial para obtenção de B. thuringiensis. O isolado BtMA-750, obtido a partir da amostra de solo da restinga, foi interessantemente distinguido por sua alta toxicidade para Ae. aegypti. Este isolado, além de apresentar proteínas com massa molecular semelhante às toxinas Cry e Cyt, apresentou também diversos genes díptero-específicos cry e cyt, demonstrando que tem alto potencial para ser usado no controle biológico de Ae. aegypti.
\end{abstract}

Palavras-chave: controle biológico, bactéria, ecossistema, vetor. 


\section{Introduction}

The Aedes (Stegomyia) aegypti (Linnaeus 1762), considered a cosmopolitan mosquito, is widely distributed among tropical and subtropical regions. This mosquito is the main vector for DENV, ZIKA and CHIKV arbovirus, which unleash infections in human, such as dengue fever, zika fever and chikungunya fever, respectively (Gubler and Clark, 1995; Donalisio and Freitas, 2015; Vasconcelos, 2015; Valle et al., 2016; Roundy et al., 2017; Brasil, 2020). These arboviruses currently represent one of the biggest public health problems in Brazil, because the vector shows a broad spread among its territory (Brasil, 2020).

The main strategies for the Ae. aegypti density reduction are: reducing larval density by eliminating breeding sites, such as artificial breeding sites (Bezerra et al., 2017; Montagner et al., 2018; Andrade et al., 2020); biological or chemical control, using entomopathogenic bacteria (Soares-da-Silva et al., 2017; Lobo et al., 2018) and insecticides, respectively (Dusfour et al., 2019). However, the insecticides contribute to the emergence of resistant mosquitoes populations, that being a latter disadvantage, for it is one of the main problems that affect the vector's control strategies (David et al., 2018; Dusfour et al., 2019).

The biological control is a sustainable alternative to reduce the vector population indexes (Huang et al., 2017). The Bacillus thuringiensis (Berliner, 1911) is an important insects' pathogen and exhibits high toxicity for diptera larvae (Campanini et al., 2012; Soares-da-Silva et al., 2017; Lobo et al., 2018; Zghal et al., 2018; Viana et al., 2020).

The $B$. thuringiensis produces protein crystals during the sporulation phase; these crystals are made of $\delta$-endotoxins or Cry and Cyt proteins (Soberón et al., 2018), encoded by cry and cyt genes, located at conjugative plasmids (Berry et al., 2002). The proteins become toxic to the larvae after they ingest them, because in the larvae's medium intestine the proteins are solubilized, due to the alkaline $\mathrm{pH}$, freeing protoxins that bind to specific receptors in the intestinal epithelium, causing the pore formation on the cellular membrane, which leads to a ionic imbalance and larval death (Soberón et al., 2018; Viana et al., 2020).

In addition to the $\delta$-endotoxins, the $B$. thuringiensis presents other toxicity mechanisms, such as quitinase enzyme production, which can enhance the bacillus' insecticide action, because this exoenzyme interrupts the membrane integrity and favors the Cry toxins' insertion on the intestinal epithelium receptors (Juárez-Hernández et al., 2015).

The $B$. thuringiensis var. israelensis (Bti) is the most powerful biological alternative for controlling some diseases' vectors around the world (Polanczyk et al., 2009; Ben-Dov, 2014). This species' larvicidal activity resides in toxic proteins encoded by the cry $4 \mathrm{Aa}, \mathrm{cry} 4 \mathrm{Ba}, \mathrm{cry} 10 \mathrm{Aa}$, cryl1 Aa, cyt $1 \mathrm{Aa}, \mathrm{cyt} 1 \mathrm{Ca}$ and $c y t 2 \mathrm{Ba}$ genes (Berry et al., 2002; Costa et al., 2010; Ben-Dov, 2014), which are used in many commercial products indicated to the Ae. aegypti control (Ben-Dov, 2014). However, most of the Bti-based products are imported, which causes an increase in the final price for the customer and decreased competition for these products compared to the chemical insecticides (Angelo et al., 2010).

Despite the diversity of Bti's Cry and Cyt proteins, which leads to the multiple complex of actions and to several levels of synergistic interactions, the decrease of Ae. aegypti's susceptibility to this bacterium is a probability, suggesting that, in the future, the constant use of Bti may lead to the emergence of resistant populations (CamachoMillán et al., 2017).

In this context, the present study investigated the toxicity, the protein content and genic content of one $B$. thuringiensis isolate against Ae. aegypti larvae, obtained from the restinga ecosystem, to the search for a lineage with genetic variability greater than Bti.

\section{Material and Methods}

\subsection{Study area}

The collections were performed between August and September 2014, in three cities located at Maranhão's seacoast, Brazil: São José de Ribamar, Raposa and São Luís. The cities are formed of restinga and mangrove ecosystems. Restinga are a typical kind of vegetation of the tropical and subtropical coast areas, with sandy soil (Serra et al., 2016). The mangrove is made of a vegetation with fluviomarine influence, exhibiting oily soils from estuarine regions and discontinuous dispersion (Brasil, 2018).

\subsubsection{Collection, isolation and identification of Bacillus thuringiensis}

Fifteen samples of soils from the restinga and the mangrove ecosystems, were collected for the isolation of B. thuringiensis. The collection points were georeferenced using the GPS (Global Positioning System) and the collects of soil, isolation, identification of $B$. thuringiensis were realized according to Soares-da-Silva et al. (2017). All the strains of $B$. thuringiensis are stored in the Entomopathogenic Bacilli Bank of Maranhão (BBENMA), located in Caxias City, Maranhão, Brazil. The isolates were labeled using the standard BBENMA nomenclature, being identified as BtMA (Bt for B. thuringiensis and MA for Maranhão), followed by the identification number of the isolation.

\subsection{Bioassays}

To determine pathogenicity against larvae of Ae. aegypti, 100 isolates of $B$. thuringiensis ( 50 from restinga ecosystem and 50 from mangrove ecosystem) were grown in liquid T3-medium (Bacto-tryptone, $1.5 \mathrm{~g}$; Bacto-tryptose, $1 \mathrm{~g}$; yeast extract, $0.75 \mathrm{~g} ; \mathrm{MnCl}_{2}, 0.0025 \mathrm{~g}$; and $50 \mathrm{mM}$ phosphate buffer, pH 6.8, 0.5 L) in $250 \mathrm{~mL}$ Erlenmeyer flasks for 5 days at $180 \mathrm{rpm}$ and $28^{\circ} \mathrm{C}$, for complete sporulation and release of the crystal proteins. After that, the suspensions were used to prepare suspensions by serial dilution $\left(10^{-1}\right.$ and $\left.10^{-2}\right)$. The $10^{-2}$ suspension was counted using a Neubauer hemocytometer, to standardize a concentration of $1 \times 10^{8}$ spores $/ \mathrm{mL}$. Three replicates of each isolate were prepared in plastic cups containing $10 \mathrm{~mL}$ of distilled water, 10 third-instar larvae of Ae. aegypti and $1 \mathrm{~mL}$ of the suspension of bacillus. For each bioassay, a replicate 
with no bacteria was prepared as the negative control. After 24 hours and 48 hours of the bacillus suspension addition, larval mortality was verified by counting living and dead larvae, being considered as dead the totally inert larvae. The larvae that did not move when touched with a sterile stick were considered dead (Costa et al., 2010).

For quantitative bioassays to the determination of $\mathrm{LC}_{50}$ and $\mathrm{LC}_{90}$, only one isolate, that caused $100 \%$ of mortality in the pathogenicity assays, were grown in NYSM medium incubated at $28{ }^{\circ} \mathrm{C}$ for 5 days, at $180 \mathrm{rpm}$, for complete sporulation and release of the crystal proteins. The obtained cultures were centrifuged at $10,000 \mathrm{x}$ g for $30 \mathrm{~min}$ at $4{ }^{\circ} \mathrm{C}$, washed with autoclaved distilled water, frozen, and lyophilized for approximately $16 \mathrm{~h}$ (Santos et al., 2012). Quantitative bioassays were performed according to the recommendations guidelines for laboratory and field testing of mosquito larvicides (WHO, 2005).

Initially, ten concentrations $(0.04,0.03,0.02,0.01$, $0.008,0.005,0.004,0.003,0.002,0.001 \mathrm{mg} / \mathrm{L})$ were tested. For each concentration, three replicates were done and for each replicate, one negative control was done. The strain Bti T04001 (Laboratory of Genetics of Bacteria, UNESP - Jaboticabal, SP) was used as positive control, testing for the same conditions of the other strains of $B$. thuringiensis. The bioassays were monitored at intervals of 24,48 , and 72 hours after the application of $B$. thuringiensis.

\subsection{Statistical analyses}

The B. thuringiensis index was calculated according to Hossain et al. (1997). Mortality data were corrected using the mortality in the control treatment (Abbott, 1925), which was always $<10 \%$. After this correction the data were submitted to Probit analysis at $\mathrm{P}<0.05$ (Finney, 1971) through the statistical program POLO-PLUS (LeOra
Software Company, 2003, Petaluna, USA) for determination of $\mathrm{LC}_{50}$ and $\mathrm{LC}_{90}$.

\subsection{DNA extraction and PCR analysis}

The InstaGene Matrix kit (Bio-Rad, São Paulo, SP, Brazil) was used to extract the genomic DNA, following the manufacturer's instructions. The PCR technique was used to detect the larvicidal presence (for dipterous), cry $4 A a$, cry $4 B a$, cryl0Aa, cryl1Aa, cryl1Ba, cyt1Aa, cyt1Ab, cyt $2 A a$ and $c h i$ genes in the $B$. thuringiensis isolate that caused higher mortality for larvae of Ae. aegypti (Table 1).

The PCR assays were run in a final volume of $25 \mu \mathrm{L}$, containing $1 \mathrm{X}$ buffer, $2 \mathrm{mM} \mathrm{MgCl}, 0.2 \mathrm{mM} \mathrm{dNTPs}, 1.0 \mu \mathrm{M}$ of each primer, $1 \mathrm{U}$ Taq DNA polymerase, and $2.0 \mu \mathrm{L}$ of the DNA template. The standard Bti T04001 was used as a positive control, and for the negative control, the DNA was replaced by ultrapure water. The genes were amplified in a Gencycler-G96G thermocycler (Biosystems, Curitiba, PR, Brazil).

To genes cry and cyt, the initial denaturation was $5 \mathrm{~min}$ at $94{ }^{\circ} \mathrm{C}$, followed by 35 cycles of $1 \mathrm{~min}$ at $94{ }^{\circ} \mathrm{C}$ for denaturation, $30 \mathrm{~s}$ at $50-53{ }^{\circ} \mathrm{C}$ for annealing, and $1 \mathrm{~min}$ at $72^{\circ} \mathrm{C}$ for polymerization, with a final extension of $7 \mathrm{~min}$ at $72{ }^{\circ} \mathrm{C}$. Initial denaturation was $5 \mathrm{~min}$ at $94{ }^{\circ} \mathrm{C}$, followed by 35 cycles of $1 \mathrm{~min}$ at $94^{\circ} \mathrm{C}$ for denaturation, $30 \mathrm{~s}$ at $50-54{ }^{\circ} \mathrm{C}$ for annealing, and $1 \mathrm{~min}$ at $72{ }^{\circ} \mathrm{C}$ for polymerization, with a final extension of $7 \mathrm{~min}$ at $72^{\circ} \mathrm{C}$. To gene chi the initial denaturation was $5 \mathrm{~min}$ at $94{ }^{\circ} \mathrm{C}$, followed by 30 cycles of $1 \mathrm{~min}$ at $94^{\circ} \mathrm{C}$ for denaturation, $1 \mathrm{~min}$ at $45^{\circ} \mathrm{C}$ for annealing, and $1.5 \mathrm{~min}$ at $72{ }^{\circ} \mathrm{C}$ for polymerization, with a final extension of $10 \mathrm{~min}$ at $72{ }^{\circ} \mathrm{C}$.

Following amplification, $3 \mu \mathrm{L}$ of the PCR product was mixed with $3 \mu$ L of blue/orange Loading Dye (Promega, São Paulo, SP, Brazil) and run in a 1\% agarose gel containing

Table 1. Primers sequences used in the PCR to amplify cry, cyt and chi genes of Bacillus thuringiensis in the strain with toxic activity against Aedes aegypti, the size of the target fragment, and the annealing temperature.

\begin{tabular}{|c|c|c|c|}
\hline Genes & Sequence & FS (bp) & $\mathrm{T}\left({ }^{\circ} \mathrm{C}\right)$ \\
\hline cry $4 A a^{*}$ & $\begin{array}{l}\text { 5'-GGGTATGGCACTCAACCCCACTT } \\
\text { 3'-GCGTGACATACCCATTTCCAGGTC }\end{array}$ & 777 & 50 \\
\hline $\operatorname{cry} 4 B a^{*}$ & $\begin{array}{l}\text { 5'-GAGAACACACCTAATCAACCAAT } \\
\text { 3'-GCGTGACATACCCATTTCCAGGTC }\end{array}$ & 347 & 52 \\
\hline $\operatorname{cry} 410 A^{*}$ & $\begin{array}{c}\text { 5'-ATTGTTGGAGTTAGTGCAGG } \\
\text { 3'-AATACTTTGGATGTGTCTTGAG }\end{array}$ & 995 & 48 \\
\hline $\operatorname{cry} 11 A^{*}$ & $\begin{array}{l}\text { 5'-CCGAACCTACTATTGCGCCA } \\
\text { 3'-CTCCCTGCTAGGATTCCGTC }\end{array}$ & 470 & 50 \\
\hline $\operatorname{cry} 11 B a^{*}$ & $\begin{array}{l}\text { 5'-CCGAACCTACTATTGCGCCA } \\
\text { 3'-TGTTCCTTTACTGCTGATAC }\end{array}$ & 608 & 52 \\
\hline cyt1Aa* & $\begin{array}{c}\text { 5'-AACTCAAACGAATAACCAAG } \\
\text { 3'-TGTTCCTTTACTGCTGATAC }\end{array}$ & 300 & 53 \\
\hline $\operatorname{cyt} 1 A b^{*}$ & $\begin{array}{c}\text { 5'-AAGCAAGGGTTATTACATTACG } \\
\text { 3'-CCAATACTAAGATCAGAGGG }\end{array}$ & 698 & 54 \\
\hline $\operatorname{cyt} 2 A a^{*}$ & $\begin{array}{l}\text { 5'-GCATTAGGAAGACCATTTG } \\
\text { 3'-AAGGCTAAGAGTTGATATCG }\end{array}$ & 361 & 53 \\
\hline$c h i^{\#}$ & $\begin{array}{c}\text { 5'-ATGGTCATGAGGTCTC } \\
\text { 3'-CTATTTCGCTAATGAGC }\end{array}$ & 2027 & 45 \\
\hline
\end{tabular}

FS (bp): Fragment size in base pairs; T: Temperature. *Primers designed by Costa et al. (2010); \#Primers designed by Lin and Xiong (2004). 
GelRed charged at $90 \mathrm{~V}$, in a TBE $1 \mathrm{X}$ (Tris/Borate/EDTA) solution at a basic $\mathrm{pH}$. A $1 \mathrm{~kb}$ DNA Ladder (Promega) was used as a marker of molecular weight. The amplification products were visualized and photographed under UV light (L-PIX EX Loccus photodocumentator system, São Paulo, SP, Brazil).

\subsection{Protein characterization of Bacillus thuringiensis isolate}

The proteins were extracted according to the protocol of Lecadet et al. (1992) and stored in a protease inhibitor solution at $-20^{\circ} \mathrm{C}$. The samples were prepared using $25 \mu \mathrm{L}$ of the spore/crystal complex, to which $25 \mu \mathrm{L}$ of sample buffer $(0.5 \mathrm{M}$ Tris- $\mathrm{HCl} \mathrm{pH} 6.8,25 \%$ glycerol, $1 \%$ blue of bromophenol, $10 \%$ SDS and $1 \% \beta$-mercaptoethanol) was added. This mixture was then boiled at $100{ }^{\circ} \mathrm{C}$ for $10 \mathrm{~min}$. An aliquot of $40 \mu \mathrm{L}$ was extracted from sample and run in a $12 \%$ polyacrylamide gel alongside a standard Broad Range Protein Molecular marker (Promega, São Paulo, SP, Brazil) as a reference for the determination of the molecular weight of the proteins. The protein profile of the $B$. thuringiensis isolate was obtained by denaturing sodium dodecyl sulfate polyacrylamide gel for electrophoresis (SDS-PAGE 12\%) (Laemmli, 1970). Bti T04001 standard was used as positive control. The sample was obtained by growing the isolate in nutrient agar, kept for five days in a bacteriological growth oven at $28{ }^{\circ} \mathrm{C}$. The electrophoresis was run in a vertical system (Kasvi) filled with $1 \mathrm{x}$ run buffer ( $25 \mathrm{mM}$ Tris-base,
$35 \mathrm{mM}$ SDS and $1.92 \mathrm{mM}$ glycine) and charged at $150 \mathrm{~V}$ for 2:30 h. After the run, the gel was stained in Comassie Brilliant Blue solution (50\% methanol, 10\% acetic acid and $0.1 \%$ Comassie Brilliant Blue R-250) for $1 \mathrm{~h}$ at room temperature, and then discolored in a 4:1 methanol: acetic acid solution for $24 \mathrm{~h}$, until visualization of the protein bands corresponding to the toxins. The gel was digitized and analyzed for the presence of proteins of interest, that is, those with insecticidal potential, based on the published data.

\section{Results}

Of the 15 samples, 284 bacterial colonies were isolated, of which $232(81.7 \%)$ were identified as B. thuringiensis. Of this total, $110(47.4 \%)$ were from the restinga soil and $122(52.6 \%)$ from the mangrove soil (Table 2). The highest number of isolates of $B$. thuringiensis per sample was verified in samples seven and fourteen from the cities of São Luís (30) and Raposa (31), respectively. The $B$. thuringiensis colonies index varied from 0 to 1.0 , with an overall average of 0.80 (Table 2).

Of the 100 isolates of $B$. thuringiensis, only the BtMA750 isolate presented pathogenicity ( $100 \%$ in less than 24 hours) against $A$ e. aegypti larvae and underwent toxicity tests. The data on concentration-mortality fit the probity model $\left(\chi^{2}\right.$ was not significant, $\mathrm{P}>0.05$ ) (Table 3 ) and the $\mathrm{LC}_{50}$ was obtained at $0.004 \mathrm{mg} / \mathrm{mL}$ and $\mathrm{CL}_{90}$ at $0.010 \mathrm{mg} / \mathrm{mL}$ (Table 3). Compared

Table 2. Bacillus thuringiensis isolates index obtained from soil samples from the restinga and mangrove ecosystems of three cities in the state of Maranhão.

\begin{tabular}{cccccc}
\hline Ecosystem & Soil Sample & City & $\mathbf{n B C}^{\mathbf{1}}$ & $\mathbf{n} B t \mathbf{C}^{\mathbf{2}}$ & $\mathbf{B t}_{\mathbf{i n d e x}}^{\mathbf{3}} \mathbf{( \% )}$ \\
\hline Restinga & 1 & São José de Ribamar & 33 & 20 & 0.60 \\
& 2 & São José de Ribamar & 16 & 16 & 1.00 \\
& 3 & São José de Ribamar & 4 & 0 & 0.00 \\
& 4 & São José de Ribamar & 2 & 1 & 0.50 \\
& 5 & São José de Ribamar & 2 & 0 & 0.00 \\
& 6 & São Luís & 25 & 24 & 0.96 \\
Mangrove & 7 & São Luís & 30 & 30 & 1.00 \\
& 8 & São Luís & 30 & 19 & 0.63 \\
& 9 & São José de Ribamar & 18 & 4 & 1.00 \\
& 10 & São José de Ribamar & 5 & 20 & 0.80 \\
& 11 & São Luís & 22 & 25 & 0.90 \\
Total & 12 & Raposa & 25 & 1 & 1.00 \\
& 13 & Raposa & 31 & 31 & 1.00 \\
& 14 & Raposa & 40 & 23 & 1.00 \\
\hline
\end{tabular}

${ }^{1}$ Number of Bacterial Colony; ${ }^{2}$ Number of Bacillus thuringiensis Colony; ${ }^{3}$ Bacillus thuringiensis isolates index calculed by $\mathrm{n}(\mathrm{BtC} / \mathrm{BC}) * 100$.

Table 3. Lethal concentrations $\mathrm{LC}_{50}$ and $\mathrm{LC}_{90}$ in $\mathrm{mg} / \mathrm{L}$ of isolate BtMA-750 pathogenic to Aedes aegypti.

\begin{tabular}{cccccc}
\hline Isolates & $\mathbf{N}^{\mathbf{1}}$ & ${\text { Slope } \pm \mathbf{S E}^{\mathbf{2}}} \mathbf{L C}_{\mathbf{5 0}}(\mathbf{C I} \mathbf{9 5} \%)^{\mathbf{3}}$ & $\mathbf{L C}_{\mathbf{9 0}}(\mathbf{C I} \mathbf{9 5} \%)^{\mathbf{3}}$ & $\mathbf{X}^{\mathbf{2}} \mathbf{( D F}^{\mathbf{4}}$ \\
\hline Bti T04 001 & 1.000 & $2.03 \pm 0.09$ & $0.003(0.002-0.004)$ & $0.012(0.009-0.018)$ & $6.68(3)$ \\
BtMA-750 & 1.000 & $3.74 \pm 0.18$ & $0.004(0.003-0.005)$ & $0.010(0.008-0.012)$ & $7.52(3)$ \\
\hline
\end{tabular}

${ }^{1}$ Total number of tested insects; ${ }^{2}$ Slope \pm Standard Error; ${ }^{3}$ Confidence Intervals; ${ }^{4}$ Chi-square and degrees of freedom; ${ }^{5}$ Bacillus thuringiensis var. israelensis T14 001. 


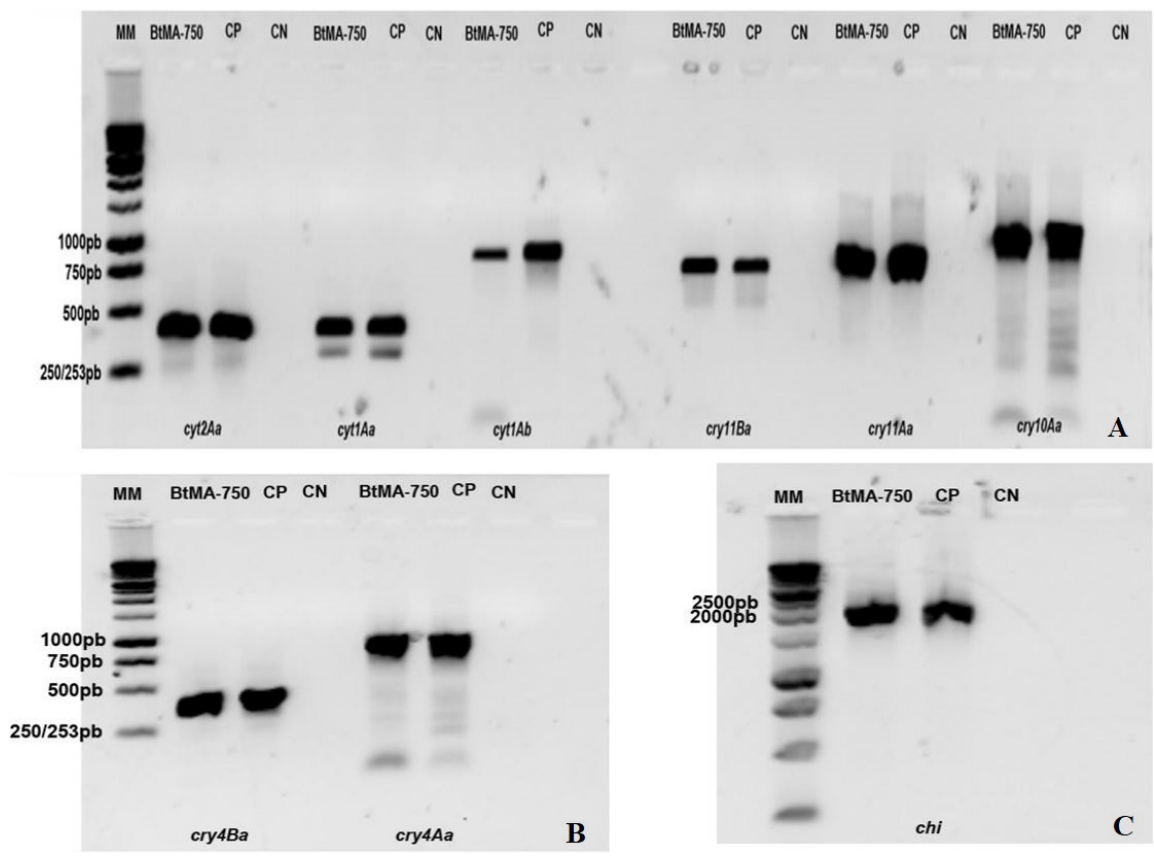

Figure 1. Amplification products obtained for isolate BtMA-750 active to Aedes aegypti using the primers: cyt1Aa, cyt1Ab, cyt $2 A a$, cry $11 A a$, cry $11 B$ a e cry $10 A a(\mathbf{A})$, cry $4 A a$, cry $4 B a(\mathbf{B})$ and chi $(\mathbf{C})$. CP: positive control; CN: negative control; MM: molecular marker (1 Kb DNA Ladder).

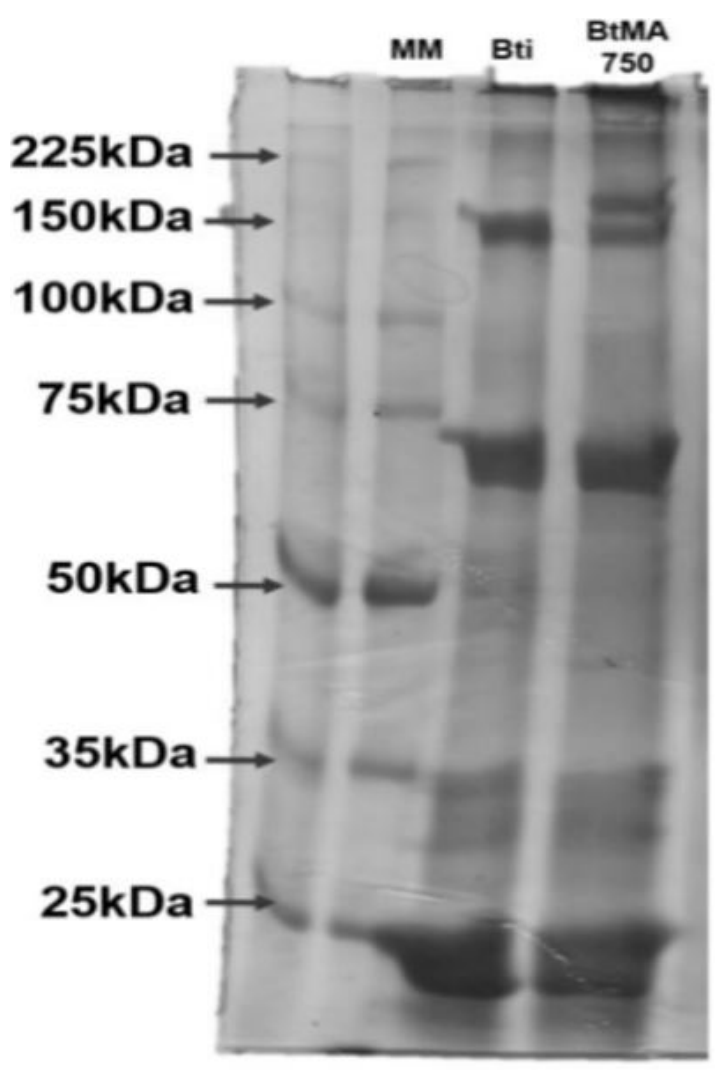

Figure 2. SDS-PAGE protein profile from active isolate BtMA-750 against Aedes aegypti. MM: molecular weight marker; Bti: Bacillus thuringiensis var. israelensis T14 001. to the $\mathrm{LC}_{50}$ and $\mathrm{CL}_{90}$ found for Bti T14 $001(0.003 \mathrm{mg} / \mathrm{mL}$ and $0.012 \mathrm{mg} / \mathrm{mL}$, respectively), it is observed that this values were very close (Table 3 ), which suggests the potential of the BtMA-750 isolate to be applied in the biological control of vectors.

The molecular analysis showed that the BtMA750 isolate amplified for all nine genes cyt $1 A a, c y t 1 A b$, cyt2Aa, cry10Aa, cry11Aa, cry $11 B a$ (Figure 1A), cry $4 A a$, $\operatorname{cry} 4 \mathrm{Ba}$ (Figure 1B) and chi (Figure 1C), with expected band sizes. As for the protein profile, proteins of molecular mass of $140 \mathrm{kDa}$ and $72 \mathrm{kDa}$ were observed, being compatible with the size of Cry4 and Cry11, respectively. Regarding the Cyt class, the isolate showed proteins of molecular mass less than $50 \mathrm{kDa}$ similar to Cyt1 and Cyt2 toxins (Figure 2). It can be verified that the BtMA-750 isolate presented a protein profile similar to that of the reference strain; however, a band bigger than $150 \mathrm{kDa}$ was verified for the isolate (Figure 2).

\section{Discussion}

The soil is the most used substrate for the isolation of B. thuringiensis (Soares-da-Silva et al., 2015; Lobo et al., 2018). In the present study, the soil of the mangrove and restinga ecosystems showed a potential to obtain this bacilli, with high variation of the $B$. thuringiensis index regarding the soil samples of the ecosystems of which they were isolated, being the average $B$. thuringiensis index of 0.81 .

This index showed that the restinga and mangrove soil had the potential to prospect the $B$. thuringiensis. As a ubiquitous bacterium, $B$. thuringiensis has been recorded 
as distributed in the soil of all types of habitats. However, most of the research report $B$. thuringiensis index lower than that shown in the present study. Soares-da-Silva et al. (2015) obtained only $11.8 \%$ of $B$. thuringiensis isolate's occurrence in loamy and sandy soils in the Amazon region and Lobo et al. (2018) reported $31.26 \%$ of $B$. thuringiensis isolate in Savannah forests' soil, which are acid and have low nutrients availability (Lopes and Cox, 1977; Lopes, 1996).

The $B$. thuringiensis' isolates index variation from the soil samples may be related to the soil's chemical proprieties, such as type of nutrients, acidity and soil oxygenation, that can influence the $B$. thuringiensis prospection and the bacterium's toxins production (Yao et al., 2002; Polanczyk et al., 2009).

Despite the high $B$. thuringiensis index, a few isolates showed high toxicity to Ae. aegyti larvae. Therefore, several studies are frequently performed aiming to isolate strains with high toxicity and greater genetic variability regarding the $B$. thuringiensis var. israelensis pattern (Soares-daSilva et al., 2015; Lobo et al., 2018; Zghal et al., 2018).

However, interestingly, despite the restinga ecosystems' soil to be sandy, chemically poor and has as its main source of nutrients the seawater (Leão and Dominguez, 2000; Almeida Júnior et al., 2009), it was from a sample of this soil, the isolate BtMA-750, the high potential for the control of Ae. aegypti.

The toxic potential of the BtMA-750 isolate, similar to the Bti T04 001 standard strain, is related to the presence of the cry and cyt genes (cry4Aa, cry $4 B a, c r y 10 A a$, cry $11 A a$, cry $11 B a, c y t 1 A a, c y t 1 A b$ and $c y t 2 A a$ ), which was confirmed by protein content analysis, in which it was possible to verify proteins with molecular mass similar to the toxins Cry4, Cry11 and Cyt, that are codified by these genes.

This combination of toxins is highly lethal for different species of mosquitoes, and is reported to act in synergism in mosquito larvae of medical importance (Pérez et al., 2005). Cry 4 A and Cry4B proteins are widely reported in isolates that exhibit toxic activity against mosquito vectors, but Cry4Ba is highly toxic to Aedes larvae, while Cry4Aa is less toxic (Beltrão and Silva-Filha, 2007; Campanini et al., 2012).

The Cry10Aa toxin presents high toxicity for $A e$. agypti, when it acts synergistically with the toxin Cyt $1 \mathrm{Aa}$. Cry11Aa is also highly toxic for the gender of mosquitos Aedes and Culex, lower for Anopheles (Revina et al., 2004; Hernández-Soto et al., 2009). B. thuringiensis isolates that are toxic for $\mathrm{Ae}$. aegypti frequently presented the $\mathrm{cry} 11 \mathrm{Aa}$ gene (Costa et al., 2010).

The larvicidal activity of the Cyt1Aa toxin is low against mosquito larvae. However, Pérez et al. (2005) and Hernández-Soto et al. (2009) reported that this toxin has the ability to act in synergism with the Cry proteins, which improves the insecticidal potential of the isolates that express these proteins. The Cyt1 Aa toxin has the property of inserting itself directly into the cell membrane, without being mediated by specific receptors; in this way, this toxin acts as a receptor molecule of the Cry toxin. Evidence has shown that the synergism between Cry11Aa and Cyt1 Aa is of high toxicity to Ae. aegypti larvae (Pérez et al., 2005).

In this way, Cyt toxins not only increase the toxicity of certain Cry toxins, but also play a critical role in delaying selection for resistance to Bti's Cry proteins (Soberón et al., 2018). The Cyt2Aa protein also exhibits high synergistic activity with Cry proteins (Promdonkoy et al., 2005). The co-expression of the toxins Cry4Ba and Cyt2Aa, made by Escherichia coli, enhanced the toxicity for Ae. aegypti and Culex quinquefasciatus, demonstrating high synergic activity between the toxins (Promdonkoy et al., 2005).

The presence of the chi gene in the BtMA-750 isolate may be contributing to the toxicity of this isolate, because this gene encodes the chitinase enzyme (damaging the peritrophic membrane), which is another mechanism of insecticidal action of $B$. thuringiensis and may be acting in synergism with $\delta$-endotoxins increasing their toxicity (Juárez-Hernández et al., 2015).

The BtMA-750 isolate presented dipteran-specific genes which are responsible for encoding insecticidal toxins. These genes are found in Bti, which is the most efficient strain used in formulations to control this mosquito in different parts of the world (Ben-Dov, 2014; Sajid et al., 2018; Soberón et al., 2018). These findings show that BtMA-750 is promising to be used in the biological control of mosquito vectors.

Therefore, it is of extreme relevance the continuous search for new isolates in the attempt to control the diseases whose vector is Ae. aegypti. The production of biopesticides formulations from lineages that are adapted to the conditions of each region would provide a highly efficient and low-cost product, and is a viable alternative to reduce the use of chemical insecticides that are harmful to man and environment, which is a problem extensively discussed. Therefore, it is of extreme relevance to obtain new isolates in an attempt to control Ae. aegypti.

New Israeli-based liquid formulated Bacillus thuringiensis, designated as BioUel, manufactured in Brazil, presented toxicity to Ae. aegypti and Cx. quinquefasciatus larvae and also presented high efficiency compared to most of the tested commercial products. The bio-insecticide stability is 90 days, approximately, therefore, its production is viable (Lopes et al., 2010).

As seen, the $B$. thuringiensis is a bacterium that is very efficient in controlling mosquito vectors, and prospection for new strains makes it possible to obtain isolates with greater genetic variability. The soil of the restinga and mangrove ecosystems of the State of Maranhão proved to be favorable for the prospection of $B$. thuringiensis isolates. In addition, this isolate, carrying different $c r y$ and cyt genes can be used to avoid resistance in Ae. aegypti in the field, a fact already confirmed by the excessive use of chemical insecticides (David et al., 2018; Dusfour et al., 2019).

In addition to the advantage of $B$. thuringiensis over chemical insecticides, it is also harmless to humans, even in extremely high doses. The bacterium is a biological insecticide highly secure (Raymond and Federici, 2017). However, in the present study, it was evidenced that, despite 
of high amount of isolates gotten from soil samples, the number of isolates with toxicity for Ae. aegypti is relatively low. Therefore, the search for new strains with greater genetic variability is a challenging activity.

Considering the high cost for the microbial insecticides production, in addition to the problem related to the loss of effectiveness of larvicides due to climatic conditions in the northern and northeastern regions of Brazil, it is important to obtain isolates of regional B. thuringiensis, which can be used as a biotechnological tool, using the natural resources of the studied region.

\section{Acknowledgements}

To professors Dr. Wanderli Pedro Tadei of Laboratory of Malaria and Dengue, INPA - Amazônia. To the Laboratory of Genetics of Bacteria, UNESP - Jaboticabal, SP. This work was funded by the FAPEMA - Fundação de Amparo à Pesquisa e Desenvolvimento Científico do Maranhão.

\section{References}

ABBOTT, W.S., 1925. A method of computing the effectiveness of an insecticide. Journal of Economic Entomology, vol. 18, no. 2, pp. 265-267. http://dx.doi.org/10.1093/jee/18.2.265a.

ALMEIDA JÚNIOR, E.B., OLIVO, M.A., ARAÚJO, E.L. and ZICKEL, C.S., 2009. Caracterização da vegetação de restinga da RPPN de Maracaípe, PE, Brasil, com base na fisionomia, flora, nutrientes do solo e lençol freático. Acta Botanica Brasílica, vol. 23 , no. 1 , pp. 36-48. http://dx.doi.org/10.1590/S010233062009000100005

ANDRADE, A.T., BEZERRA, J.M.T. and PINHEIRO, V.C.S., 2020 [viewed 22 March 2020]. Characterization of the Proliferation Sites of Aedes aegypti (Diptera: Culicidae) in the Artificial Breeding Sites of Caxias, Maranhão, Brazil. In: M. SARWAR, ed. Life cycle and development of Diptera [online] London: IntechOpen. Available from: https://cdn.intechopen.com/pdfs/69875.pdf

ANGELO, E.A., VILAS-BÔAS, G.T. and CASTRO-GÓMEZ, R.J.H., 2010. Bacillus thuringiensis: características gerais e fermentação. Semina: Ciências Agrárias, vol. 31, no. 4, pp. 945-948. http://dx.doi.org/10.5433/1679-0359.2010v31n4p945.

BELTRÃO, H.B.M. and SILVA-FILHA, M.H.N., 2007. Interaction of Bacillus thuringiensis var. israelensis Cry toxins with binding sites from Aedes aegypti (Diptera: Culicidae) larvae midgut. FEMS Microbiology Letters, vol. 266, no. 2, pp. 163-169. http:// dx.doi.org/10.1111/j.1574-6968.2006.00527.x. PMid:17132151.

BEN-DOV, E., 2014. Bacillus thuringiensis subsp. israelensis and its dipteran-specific toxins. Toxins, vol. 6, no. 4, pp. 12221243. http://dx.doi.org/10.3390/toxins6041222. PMid:24686769.

BERRY, C., O'NEIL, S., BEN-DOV, E., JONES, A.F., MURPHY, L., QUAIL, M.A., HOLDEN, M.T.G., HARRIS, D., ZARITSKY, A. and PARKHILL, J., 2002. Complete sequence and organization of pBtoxis, the toxin-coding plasmid of Bacillus thuringiensis subsp. israelensis. Applied and Environmental Microbiology, vol. 68 , no. 10 , pp. 5082-5095. http://dx.doi.org/10.1128/ AEM.68.10.5082-5095.2002. PMid:12324359.

BEZERRA, J.M.T., SANTANA, I.N.S., MIRANDA, J.P., TADEI, W.P. and PINHEIRO, V.C.S., 2017. Breeding sites of Aedes aegypti (Linnaeus) (Diptera, Culicidae): study about the containers in dry and rainy seasons in dengue-endemic city. Revista de Pesquisa em Saúde., vol. 18, no. 2, pp. 102-107.

BRASIL. Ministério do Meio Ambiente. Instituto Chico Mendes de Conservação da Biodiversidade - ICMBio, 2018. Atlas dos manguezais do Brasil. Brasília: ICMBio, 176 p

BRASIL. Ministério da Saúde. Secretaria de Vigilância em Saúde, 2020 [viewed 22 March 2020]. Monitoramento dos casos de arboviroses urbanas transmitidas pelo Aedes (dengue, chikungunya e Zika), Semanas Epidemiológicas 1 a 7, 2020 [online]. Brasília: Secretaria de Vigilância em Saúde. Boletim Epidemiológico, no. 10. Available from: https://www.saude.gov.br/images/pdf/2020/ marco/06/Boletim-epidemiologico-SVS-10.pdf

CAMACHO-MILLÁN, R., AGUILAR-MEDINA, E.M., QUEZADA, H., MEDINA-CONTRERAS, O., PATIÑO-LÓPEZ, G., CÁRDENAS-COTA, H.M. and RAMOS-PAYÁN, R., 2017. Characterization of Cry toxins from autochthonous Bacillus thuringiensis isolates from Mexico. Boletín Médico del Hospital Infantil de México, vol. 74, no. 3, pp. 193-199. http://dx.doi. org/10.1016/j.bmhimx.2017.03.002. PMid:29382486.

CAMPANINI, E.B., DAVOLOS, C.C., ALVES, E.C.C. and LEMOS, M.V.F., 2012. Isolation of Bacillus thuringiensis strains that contain Dipteran-specific cry genes from Ilha Bela (São Paulo, Brazil) soil samples. Brazilian Journal of Biology = Revista Brasileira de Biologia, vol. 72, no. 2, pp. 243-247. http:// dx.doi.org/10.1590/S1519-69842012000200003. PMid:22735130.

COSTA, J.R.V., ROSSI, J.R., MARUCCI, S.C., ALVES, E.C.C., VOLPE, H.X.L., FERRAUDO, A.S., LEMOS, M.V.F. and DESIDÉRIO, J.Á., 2010. Atividade tóxica de isolados de Bacillus thuringiensis a larvas de Aedes aegypti (L.) (Diptera: culicidae). Neotropical Entomology, vol. 39, no. 5, pp. 757-766. http://dx.doi. org/10.1590/S1519-566X2010000500015. PMid:21120386.

DAVID, M.R., GARCIA, G.A., VALLE, D. and MACIEL-DEFREITAS, R., 2018. Insecticide resistance and fitness: the case of four Aedes aegypti populations from different brazilian regions. BioMed Research International, vol. 2018, pp. 6257860. http:// dx.doi.org/10.1155/2018/6257860. PMid:30402487.

DONALISIO, M. and FREITAS, A.R.R., 2015. Chikungunya no Brasil: um desafio emergente. Revista Brasileira de Epidemiologia, vol. 18, no. 1, pp. 283-285. http://dx.doi.org/10.1590/19805497201500010022. PMid:25651028.

DUSFOUR, I., VONTAS, J., DAVID, J.P., WEETMAN, D., FONSECA, D.M., CORBEL, V., RAGHAVENDRA, K., COULIBALY, M.B., MARTINS, A.J., KASAI, S. and CHANDRE, F., 2019. Management of insecticide resistance in the major Aedes vectors of arboviruses: advances and challenges. PLoS Neglected Tropical Diseases, vol. 13, no. 10, pp. e0007615. http://dx.doi. org/10.1371/journal.pntd.0007615. PMid:31600206.

FINNEY, D.J., 1971. Probit analysis. London: Cambridge University.

GUBLER, D.J. and CLARK, G.G., 1995. Dengue/dengue hemorrhagic fever: the emergence of a global health problem. Emerging Infectious Diseases, vol. 1, no. 2, pp. 55-57. http:// dx.doi.org/10.3201/eid0102.952004. PMid:8903160.

HERNÁNDEZ-SOTO, A., DEL RINCÓN-CASTRO, M.C., ESPINOZA, A.M. and IBARRA, J.R., 2009. Parasporal body formation via overexpression of the Cry10Aa toxin of Bacillus thuringiensis subsp. israelensis, and Cry10Aa-Cyt1Aa synergism. Applied and Environmental Microbiology, vol. 75, no. 14, pp. 46614667. http://dx.doi.org/10.1128/AEM.00409-09. PMid:19465527. 
HOSSAIN, M.A., AHMED, S. and HOQUE, S., 1997. Abundance and distribution of Bacillus thuringiensis in the agricultural soil of Bangladesh. Journal of Invertebrate Pathology, vol. 70, no. 3, pp. 221-225. http://dx.doi.org/10.1006/jipa.1997.4694. PMid:9367730.

HUANG, Y.S., HIGGS, S. and VANLANDINGHAM, D.L., 2017. Biological control strategies for mosquito vectors of arboviruses. Insects, vol. 8, no. 1, pp. 1-25. http://dx.doi.org/10.3390/ insects8010021. PMid:28208639.

JUÁREZ-HERNÁNDEZ, E.O., CASADOS-VÁZQUEZ, L.E., DEL RINCÓN-CASTRO, M.C., SALCEDO-HERNÁNDEZ, R., BIDESHI, D.K. and BARBOZA-CORONA, J.E., 2015. Bacillus thuringiensis subsp. israelensis producing endochitinase ChiA74Dsp inclusions and its improved activity against Aedes aegypti. Journal of Applied Microbiology, vol. 119, no. 6, pp. 1692-1699. http://dx.doi.org/10.1111/jam.12962. PMid:26434743.

LAEMMLI, U.K., 1970. Cleavage of structural proteins during the assembly of the head of bacteriophage T4. Nature, vol. 227, no. 5259, pp. 680-685. http://dx.doi.org/10.1038/227680a0. PMid:5432063.

LEÃO, Z.M.A.N. and DOMINGUEZ, J.M.L., 2000. Tropical coast of Brazil. Marine Pollution Bulletin, vol. 41, no. 1-6, pp. 112-122. http://dx.doi.org/10.1016/S0025-326X(00)00105-3.

LECADET, M.M., CHAUFAUX, J., RIBIER, J. and LERECLUS, D., 1992. Construction of novel Bacillus thuringiensis strains with different insecticidal activities by transduction and transformation. Applied and Environmental Microbiology, vol. 58, no. 3, pp. 840-849. http://dx.doi.org/10.1128/AEM.58.3.840-849.1992. PMid:16348674.

LEORA SOFTWARE COMPANY, 2003. PoloPlus: probit and logit analysis. User's guide, version 2.0. Petaluma, CA: LeOra Software Company.

LIN, Y. and XIONG, G., 2004. Molecular cloning and sequence analysis of the chitinase gene from Bacillus thuringiensis serovar alesti. Biotechnology Letters, vol. 26, no. 8, pp. 635-639. http:// dx.doi.org/10.1023/B:BILE.0000023021.50213.ed. PMid:15200172.

LOBO, K.S., SOARES-DA-SILVA, J., SILVA, M.C., TADEI, W.P., POLANCZYK, R.A. and PINHEIRO, V.C.S., 2018. Isolation and molecular characterization of Bacillus thuringiensis found in soils of the Cerrado region of Brazil, and their toxicity to Aedes aegypti larvae. Revista Brasileira de Entomologia, vol. 62, no. 1, pp. 5-12. http://dx.doi.org/10.1016/j.rbe.2017.11.004.

LOPES, A.S., 1996 [viewed 27 March 2020]. Soils under Cerrado: a success story in soil management. Better Crops International [online], vol. 10, no. 2, pp. 9-15. Available from: https://pdfs. semanticscholar.org/7697/9e2b8062e55dab64816d6c90414e c15b14f3.pdf?_ga=2.227951261.1806698549.15853161001514246622.1585316100

LOPES, A.S. and COX, R.F., 1977. A survey of the fertility status of surface soils under "cerrado" vegetation in Brazil. Soil Science Society of America Journal, vol. 41, no. 4, pp. 742-747. http://dx.doi.org/10.2136/sssaj1977.03615995004100040026x.

LOPES, J., ARANTES, O.M.N. and CENCI, M.A., 2010. Avaliação de uma nova formulação de Bacillus thuringiensis israelensis. Brazilian Journal of Biology = Revista Brasileira de Biologia, vol. 70, no. 4, pp. 1109-1113. http://dx.doi.org/10.1590/S151969842010000500029. PMid:21180922.

MONTAGNER, F.R.G., SILVA, O.S. and JAHNKE, S.M., 2018. Mosquito species occurrence in association with landscape composition in green urban areas. Brazilian Journal of Biology
= Revista Brasileira de Biologia, vol. 78, no. 2, pp. 233-239. http://dx.doi.org/10.1590/1519-6984.04416. PMid:28793030.

PÉREZ, C., FERNANDEZ, L.E., SUN, J., FOLCH, J.L., GILL, S.S., SOBERÓN, M. and BRAVO, A., 2005. Bacillus thuringiensis subsp. israelensis Cyt1Aa synergizes Cry11Aa toxin by functioning as a membrane-bound receptor. Proceedings of the National Academy of Sciences of the United States of America, vol. 102, no. 51, pp. 18303-18308. http://dx.doi.org/10.1073/ pnas.0505494102. PMid:16339907.

POLANCZYK, R.A., ZANUNCIO, J.C. and ALVES, S.B., 2009. Relationship between chemical properties of the soil and the occurrence of Bacillus thuringiensis. Ciência Rural, vol. 39, no. 1, pp. 1-5. http://dx.doi.org/10.1590/S0103-84782009000100001.

PROMDONKOY, B., PROMDONKOY, P. and PANYIM, S., 2005. Co-expression of Bacillus thuringiensis Cry4Ba and Cyt2Aa2 in Escherichia coli revealed high synergism against Aedes aegypti and Culex quinquefasciatus larvae. FEMS Microbiology Letters, vol. 252, no. 1, pp. 121-126. http://dx.doi.org/10.1016/j. femsle.2005.08.038. PMid:16168580.

RAYMOND, B. and FEDERICI, B.A., 2017. In defense of Bacillus thuringiensis, the safest and most successful microbial insecticide available to humanity: a response to EFSA. FEMS Microbiology Ecology, vol. 93, no. 7, pp. fix084. http://dx.doi. org/10.1093/femsec/fix084. PMid:28645183.

REVINA, L.P., KOSTINA, L.I., GANUSHKINA, L.A., MIKHAILOVA, A.L., ZALUNIN, I.A. and CHESTUKHINA, G.G., 2004. Reconstruction of Bacillus thuringiensis ssp. israelensis Cry11A endotoxin from fragments corresponding to its $\mathrm{N}$ - and $\mathrm{C}$ moieties restores its original biological activity. Biochemistry, vol. 69, no. 2, pp. 181-187. http://dx.doi.org/10.1023/ B:BIRY.0000018949.70836.dc. PMid:15000685.

ROUNDY, C.M., AZAR, S.R., ROSSI, S.L., HUANG, J.H., LEAL, G., YUN, R., FERNANDEZ-SALAS, I., VITEK, C.J., PAPLOSKI, I.A., KITRON, U., RIBEIRO, G.S., HANLEY, K.A., WEAVER, S.C. and VASILAKIS, N., 2017. Variation in Aedes aegypti mosquito competence for zika. Emerging Infectious Diseases, vol. 23, no. 4, pp. 625-632. http://dx.doi.org/10.3201/ eid2304.161484. PMid:28287375.

SAJID, M., GENG, C.E., LI, M., WANG, Y., LIU, H., ZHENG, J., PENG, D. and SUN, M., 2018. Whole-genome analysis of bacillus thuringiensis revealing partial genes as a source of novel cry toxins. Applied and Environmental Microbiology, vol. 84, no. 14, pp. e00277-18. http://dx.doi.org/10.1128/AEM.00277-18. PMid:29752275.

SANTOS, F.P., LOPES, J., VILAS-BÔAS, G.T. and ZEQUI, J.A., 2012. Characterization of Bacillus thuringiensis isolates with potential for control of Aedes aegypti (Linnaeus, 1762) (Diptera: culicidae). Acta Tropica, vol. 122, no. 1, pp. 64-70. http://dx.doi. org/10.1016/j.actatropica.2011.11.018. PMid:22178674.

SERRA, F.C.V., LIMA, P.B. and ALMEIDA JÚNIOR, E.B., 2016. Species richness in restinga vegetation on the eastern Maranhão State, Northeastern Brazil. Acta Amazonica, vol. 46, no. 3, pp. 271-280. http://dx.doi.org/10.1590/1809-4392201504704.

SOARES-DA-SILVA, J., PINHEIRO, V.C.S., LITAIFF-ABREU, E., POLANCZYK, R.A. and TADEI, W.P., 2015. Isolation of Bacillus thuringiensis from the state of Amazonas, in Brazil, and screening against Aedes aegypti (Diptera, Culicidae). Revista Brasileira de Entomologia, vol. 59, no. 1, pp. 1-6. http://dx.doi. org/10.1016/j.rbe.2015.02.001. 
SOARES-DA-SILVA, J., QUEIRÓS, S.G., AGUIAR, J.S., VIANA, J.L., VIEIRA-NETA, M.R.A., SILVA, M.C., PINHEIRO, V.C.S., POLANCZYK, R.A., CARVALHO-ZILSE, G.A. and TADEI, W.P., 2017. Molecular characterization of the gene profile of Bacillus thuringiensis Berliner isolated from brazilian ecosystems and showing pathogenic activity against mosquito larvae of medical importance. Acta Tropica, vol. 176, pp. 197-205. http://dx.doi.org/10.1016/j.actatropica.2017.08.006. PMid:28823909.

SOBERÓN, M., MONNERAT, R. and BRAVO, A., 2018. Mode of action of cry toxins from Bacillus thuringiensis and resistance mechanisms. In: P. GOPALAKRISHNAKONE, B. STILES, A. ALAPE-GIRÓN, J.D. DUBREUIL and M. MANDAL, eds. Microbial toxins: toxinology. Dordrecht: Springer, pp. 1-13.

VALLE, D., PIMENTA, D.N. and AGUIAR, R., 2016. Zika, dengue e chikungunya: desafios e questões. Epidemiologia e Serviços de Saúde : Revista do Sistema Unico de Saúde do Brasil, vol. 25, no. 2, pp. 419-422. http://dx.doi.org/10.5123/ S1679-49742016000200020. PMid:27869959.

VASCONCELOS, P.F.C., 2015. Doença pelo vírus Zika: um novo problema emergente nas Américas? Revista Pan-Amazônica de Saúde, vol. 6, no. 2, pp. 9-10. http://dx.doi.org/10.5123/S217662232015000200001 .
VIANA, J.L., SOARES-DA-SILVA, J., VIEIRA-NETA, M.R.A., TADEI, W.P., OLIVEIRA, C.D., ABDALLA, F.C., PEIXOTO, C.A. and PINHEIRO, V.C.S., 2020. Isolates of Bacillus thuringiensis from Maranhão biomes with potential insecticidal action against Aedes aegypti larvae (Diptera, Culicidae). Brazilian Journal of Biology = Revista Brasileira de Biologia. In press. http://dx.doi. org/10.1590/1519-6984.223389. PMid:32130286.

WORLD HEALTH ORGANIZATION - WHO, 2005 [viewed 25 January 2019]. WHO/CDS/WHOPES/GCDPP/2005: guidelines for laboratory and field testing of mosquito larvicides [online]. Geneva: WHO, 13 p. Available from: https://apps.who.int/iris/ handle/10665/69101

YAO, J., LIU, Y., GAO, Z.-T., LIU, P., SUN, M., ZOU, X., QU, S.S. and YU, Z.-N., 2002. Microcalorimetric study on the biological effects of $\mathrm{Zn}^{+2}$ on Bacillus thuringiensis growth. Chinese Journal of Chemistry, vol. 20, no. 8, pp. 746-752. http://dx.doi. org/10.1002/cjoc.20020200808.

ZGHAL, R.Z., GHEDIRA, K., ELLEUCH, J., KHARRAT, M. and TOUNSI, S., 2018. Genome sequence analysis of a novel Bacillus thuringiensis strain BLB406 active against Aedes aegypti larvae, a novel potential bioinsecticide. International Journal of Biological Macromolecules, vol. 116, pp. 1153-1162. http:// dx.doi.org/10.1016/j.ijbiomac.2018.05.119. PMid:29778876. 